\title{
Bethlem Myopathy 1
}

National Cancer Institute

\section{Source}

National Cancer Institute. Bethlem Myopathy 1. NCI Thesaurus. Code C126688.

A usually autosomal dominant inherited movement disorder caused by mutations in the COL6A1, COL6A2, and COL6A3 genes. It is characterized by prog ressive muscle weakness and joint stiffness in the fingers, wrists, elbows, and ankles. 